\title{
Article
}

\section{Relationship of Thyroid Hormones with Heart Rate Variability}

\author{
Rassel Kabir ${ }^{1}$, Noorzahan Begum², Sultana Ferdousi ${ }^{3}$, Shelina Begum ${ }^{4}$, Taskina Ali5
}

\begin{abstract}
Background: Altered thyroid functions are associated with variation in autonomic regulation of cardiovascular activity. Cardiac Autonomic Nervous Activity (CANA) can be assessed quantitatively by analysis of Heart Rate Variability (HRV). Objective: To observe the relationship between CANA with altered TSH and $\mathrm{FT}_{4}$. Methods: This cross sectional study was carried out in the Department of Physiology, BSMMU, Dhaka between $1^{\text {st }}$ July 2007 and $30^{\text {th }}$ June 2008 on 60 patients with excess thyroid hormone (group B, aged 30-50 years). Based on treatment, 30 untreated newly diagnosed patients were designated as group $\mathrm{B}_{1}$ and 30 patients under treatment with antithyroid drugs for at least 2 months were included into group $B_{2}$ in order to observe the effect of treatment. All these patients were selected from the Out Patient Department of Endocrinology wing of Department of Medicine, BSMMU, Dhaka. Sociodemographically matched 20 apparently healthy euthyroid persons were selected for comparison (group A). To confirm thyroid status, serum TSH and serum $\mathrm{FT}_{4}$ levels were measured by AxSym system and some of the spectral HRV parameters i.e.mean R-R interval, mean heart rate, variance, LF n.u, HF n.u and LF/HF ratio were assessed by recordings of ECG for 5 minute (short term) with a polyrite. For statistical analysis Pearson's correlation coefficient (r) test was used. Results: With serum TSH level, the LF n.u. power and LF/HF ratio showed significant $(\mathrm{p}<0.05)$ positive correlations but HF n.u. power showed significant $(\mathrm{p}<0.05)$ negative correlation in group $\mathrm{B}_{1}$. But these three parameters showed non significant correlations with TSH in the other two groups (A, $\mathrm{B}_{2}$ ). Similarly with serum TSH level, variance and mean R-R interval showed negative and mean HR showed positive correlation in group $\mathrm{B}_{1}$. In group $\mathrm{A}$, all these parameters were positively correlated whereas in group $\mathrm{B}_{2}$, RR interval and variance were positively and mean $\mathrm{HR}$ was negatively correlated. All these correlations were statistically non significant. With serum $\mathrm{FT}_{4}$ levels, mean R-R and HF n.u. were negatively and mean heart rate, LFnu, LF/HF were positively correlated in all three groups but variance showed positive in group $A$ and negative correlation in $B_{1}$ and $B_{2}$. All these correlations were statistically non significant. Conclusion: From this study it can be concluded that changes in autonomic nervous regulation are related to altered serum level of TSH and $\mathrm{FT}_{4}$ in hyperthyroids.
\end{abstract}

Key words: HRV, LF, HF, RR interval, Hyperthyroid

J Bangladesh Soc Physiol. 2010 June; 5(1): 20-26 For author affiliations, see end of text.

http://www.banglajol.info/index.php/JBSP

\section{Introduction:}

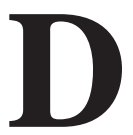

eviation of normal thyroid hormonal status has influence on cardiovascular system. Changes of serum thyroid hormone levels are related to alteration in CANA. ${ }^{1,2}$
Hyperthyroidism demonstrated lower turnover rate of catecholamines. ${ }^{3,4}$ Beta-receptor blockers increase sympathetic activity in hyperthyroid patients. ${ }^{2,5-8}$ In hyperthyroidism there is alteration of catecholamine binding

J Bangladesh Soc Physiol. 2010 June; 5(1): 20-26 
receptors or change in affinity or mechanism of action. ${ }^{8-11}$

The vagal effect on heart rate is reduced in hyperthyroids. 12-15 Moreover there is sympathovagal imbalance in hyperthyroidism. ${ }^{16}$ It has also been shown that excess thyroid hormone decreases peripheral resistance, enhances heart rate, contractility and cardiac output. 6,17-20 The thyroid hormone has direct effect on exaggeration of sinus nodal rhythmicity. 21,22 Moreover, it also reduces the excitability of cardiac parasympathetic nerves in CNS.

Power spectral analysis of HRV demonstrates the CANA, which is highly accepted for detection of sympatho-vagal imbalance. 23 Many researchers have observed that sympathoadrenal axis is changed in hyperthyroid patients. Again, others reported exaggerated sympathetic efferent outflow in hyperthyroids. 8,16,25,26

On the other hand researchers also reported that hyperthyroidism determines the degree of reduction of vagal efferent. Therefore, heart rate is mediated by relative hypersympathetic tone. 14 At the same time, observation of hyperactivity of SA node was reported in hyperthyroid patients. ${ }^{14,21}$

A variation in the heart rate, that is higher rate in hyperthyroids was reported by some researchers. ${ }^{12}$ Again, some investigators had observed lower heart rate in hyperthyroids after treatment. It has also been reported that lower R$\mathrm{R}$ interval in untreated hyperthyroid patients indicates reduced parasympathetic regulation. ${ }^{13}$, $14,21,27,28$

Lower values in time domain measures of HRV of untreated hyperthyroids was observed by many researchers. ${ }^{16,24,29}$ Some studies reported lower value of variance in untreated hyperthyroids $8,14,16,30$ and some observed higher value of this parameter in treated hyperthyroid patients.

Some investigators had observed lower LF and HF power in untreated hyperthyroids than those of healthy control. ${ }^{14,31}$

J Bangladesh Soc Physiol. 2010 June; 5(1): 20-26
LF n.u. and HF n.u. were higher in untreated hyperthyroid patients in comparison to healthy control group. ${ }^{14}$ Similarly, higher LF/HF ratios in untreated hyperthyroids compared to euthyroids and treated hyperthyroid were reported by many researchers $8,14,16,29$.

Hyperthyroidism is one of the common endocrine disorder in Bangladesh. Different cardiovascular and metabolic disorders may be associated with this excess thyroid hormone status. Now a day, it is quite possible to prevent the development of different systemic complications and return the life expectancy to normal. But no such study yet was under taken to observe the relationship of HRV measures with the thyroid hormones in hyperthyroidism.

Therefore, this study was carried out to assess the CANA in hyperthyroid patients in order to find out the correlation of HRV parameters with thyroid hormones. It is expected that the outcome of this study may be useful in searching the relations of these hormones with CANA, so that early treatment can be helpful for the patients.

\section{Methods}

This cross sectional study was carried out in the Department of Physiology, Bangabandhu Sheikh Mujib Medical University from $1^{\text {st }}$ July 2007 to $30^{\text {th }}$ June 2008. to observe the relationship between CANA and excess thyroidal activity in hyperthyroid patients. For this, 60 hyperthyroid patients (group B) with age ranged from 30-50 years were selected. On the basis of treatment, they were divided into group $\mathrm{B}_{1}$ consisting of untreated patients on their $1^{\text {st }}$ day of diagnosis and group $\mathrm{B}_{2}$ consisting of patients treated for at least 2 months. For comparison, 20 age and sex matched apparently healthy euthyroid subjects (group A) were also studied. The study group was selected from the Out Patient Department of Endocrinology, BSMMU, Dhaka. Subjects with history of any heart diseases, hypertension, diabetes mellitus, renal diseases, psychiatric disorders, hyperthyroidism due to 
Article

exogenous L-thyroxine, pregnancy and smoking were excluded from the study. After selection, the subject was informed about the aims, objectives and detail procedure of the study before examination and collection of blood sample. He or she was encouraged for voluntary participation and was allowed freedom to withdraw from the study whenever he or she liked, even after participation. If he or she agreed to enroll to the study, informed written consent was taken from him / her. Then the subject was prepared for the study by giving advice to have their meal by 9:00 pm, free from any physical or mental stress, not to take sedatives or any drugs affecting central nervous system and had a good sleep at night before the day of examination. He or she was advised to avoid tea or coffee at breakfast and was asked to attend the Department of Physiology of Bangabandhu Sheikh Mujib Medical University between 9:00 a.m. to 11:00 a.m. on the day of examination. Then the subject was taken to Autonomic Nerve Function Test Laboratory and detail history was taken. Then his / her thorough physical examinations were done and all informations were recorded in a prefixed questionnaire. Then he or she was kept under complete bed rest in supine position for 15-20 minutes in a cool and calm environment. During this period the subject was advised not to talk, eat or drink and also not to perform any physical or mental activity, even sleep. Then all preparations for recording of the Heart Rate Variability parameters were made by connecting the channels of ECG and Pulse to a polygraph for 5 minutes (short term). After recording of HRV parameters, $5 \mathrm{ml}$ of venous blood was drawn from the subject. Serum TSH and serum $\mathrm{FT}_{4}$ levels were measured by AxSYM system ${ }^{25}$. Heart Rate Variability parameters in both time domain and frequency domain method (in short term) were collected from Polygraphic recording.Mean RR interval,Mean HR, Variancea for time domain and
Relationship of Thyroid Hormones with HRV

LF nu,HF nu,LF/HF for frequency domain were measured For statistical analysis Pearson's correlation coefficient (r) test was done.

\section{Results}

Anthropometric details of all the groups are presented in Table I. Groups were matched for age, sex and height. The median body weight and BMI were significantly $(\mathrm{p}<0.001)$ lower in group $\mathrm{B}_{1}$ compared to those of group $\mathrm{A}$ and $\mathrm{B}_{2}$. But no significant differences of these values were observed between group $A$ and $B_{2}$.

The median value of TSH was significantly lower $(\mathrm{p}<0.001)$ and $\mathrm{FT}_{4}$ was higher $(\mathrm{p}<0.001)$ in group $\mathrm{B}_{1}$ and $\mathrm{B}_{2}$ than those of $\mathrm{A}$. Again though $\mathrm{FT}_{4}$ was significantly $(p<0.001)$ lower in group $B_{2}$ than that of $\mathrm{B}_{1}$ but TSH levels were almost similar in both the groups. (Table II).

With serum TSH level, all the parameters of HRV showed positive but nonsignificant except LF n.u. and LF/HF ratio, which showed negative correlation in group A. Again LF n.u. and LF/HF ratio showed positive and significant $(\mathrm{p}<0.05)$ whereas HF n.u showed negative but significant $(p<0.05)$ correlation with serum TSH in group $B_{1}$. Once more mean $\mathrm{R}-\mathrm{R}$ interval and variance established nonsignificant and negative but mean heart rate showed positive correlation with the same parameter in the same group. Moreover in group $B_{2}$ all the HRV parameters showed positive but nonsignificant except mean heart rate and HF n.u, which were negatively correlated with serum TSH (Table III).

Once more all the parameters of HRV showed positive but nonsignificant correlation in all the groups except mean heart rate and HF n.u. in group A, mean R-R interval, variance and HF n.u in group $B_{1}$ and mean R-R interval and HF n.u in group $B_{2}$, which showed negative correlation, with serum $\mathrm{FT}_{4}$ level (Table IV).

J Bangladesh Soc Physiol. 2010 June; 5(1): 20-26 
Relationship of Thyroid Hormones with HRV

Article

Table I : Anthropometric measures in different groups $(\mathrm{n}=80)$

\begin{tabular}{lccccc}
\hline Groups & Age(years) & Sex & Height(cm) & Weight $(\mathrm{kg})$ & BMI $\left(\mathrm{kg} / \mathrm{m}^{2}\right)$ \\
\hline $\mathrm{A}(\mathrm{n}=20)$ & $38.5^{\mathrm{a} 39.15^{\mathrm{b}}}$ & $\mathrm{M}=8 \mathrm{~F}=12$ & $160^{\mathrm{a}} 160^{\mathrm{b}}$ & $53.5^{\mathrm{a}} 54.1^{\mathrm{b}}$ & $20.87^{\mathrm{a}} 21.00^{\mathrm{b}}$ \\
$\mathrm{B}_{1}(\mathrm{n}=30)$ & $35.5^{\mathrm{a} 38.87^{\mathrm{b}}}$ & $\mathrm{M}=10 \mathrm{~F}=20$ & $157^{\mathrm{a}} 160^{\mathrm{b}}$ & $43^{\mathrm{a}} 46.05^{\mathrm{b}}$ & $17.77^{\mathrm{a}} 17.83^{\mathrm{b}}$ \\
$\mathrm{B}_{2}(\mathrm{n}=30)$ & $41^{\mathrm{a}} 40.8^{\mathrm{b}}$ & $\mathrm{M}=14 \mathrm{~F}=16$ & $159^{\mathrm{a}} 161^{\mathrm{b}}$ & $49.5^{\mathrm{a}} 52.77^{\mathrm{b}}$ & $20.02^{\mathrm{a}} 20.13^{\mathrm{b}}$ \\
\hline Statistical analysis & & & & \\
\hline Groups & $0.882^{\mathrm{ns}}$ & $\mathrm{M}=0.637^{\mathrm{nsF}=} 0.106^{\mathrm{ns}}$ & $0.904^{\mathrm{ns}}$ & $0.000^{* * *}$ & $0.000^{* * *}$ \\
\hline A vs B $_{1}$ & $0.366^{\mathrm{ns}}$ & $\mathrm{M}=0.201^{\mathrm{nsF}=} 0.336^{\mathrm{ns}}$ & $0.448^{\mathrm{ns}}$ & $0.475^{\mathrm{ns}}$ & $0.212^{\mathrm{ns}}$ \\
A vs B $_{2}$ & $0.251^{\mathrm{ns}}$ & $\mathrm{M}=0.414^{\mathrm{nsF}=} 0.505^{\mathrm{ns}}$ & $0.478^{\mathrm{ns}}$ & $0.000^{* * *}$ & $0.000^{* * *}$ \\
$\mathrm{~B}_{1}$ vs B $_{2}$ & & & &
\end{tabular}

Data were expressed as ${ }^{\mathrm{a}}$ median and ${ }^{\mathrm{b}}$ mean. For statistical analysis, $* * *=\mathrm{p}<0.001$, ns $=\mathrm{p}>0.05$.

Table II: Serum TSH and $\mathrm{FT}_{4}$ level in different groups $(\mathrm{n}=80)$

\begin{tabular}{lcl}
\hline Groups & TSH(mIU/L) & $\mathrm{FT}_{4}(\mathrm{pmol} / \mathrm{L})$ \\
\hline $\mathrm{A}(\mathrm{n}=20)$ & $3.11^{\mathrm{a} 2.79^{\mathrm{b}}}$ & $10.25^{\mathrm{a}} 10.81^{\mathrm{b}}$ \\
$\mathrm{B}_{1}(\mathrm{n}=30)$ & $0.01^{\mathrm{a}} 0.023^{\mathrm{b}}$ & $51.03^{\mathrm{a}} 51.35^{\mathrm{b}}$ \\
$\mathrm{B}_{2}(\mathrm{n}=30)$ & $0.01^{\mathrm{a}} 0.022^{\mathrm{b}}$ & $25.06^{\mathrm{a}} 30.39^{\mathrm{b}}$ \\
\hline Statistical analysis & \\
\hline Groups & P value & \\
\hline A vs $\mathrm{B}_{1}$ & $0.000^{* * *}$ & $0.000^{* * *}$ \\
A vs B $\mathrm{B}_{2}$ & $0.000^{* * *}$ & $0.000^{* * *}$ \\
$\mathrm{~B}_{1}$ vs B $_{2}$ & $0.627^{\mathrm{ns}}$ & $0.000^{* * *}$ \\
\hline
\end{tabular}

Data were expressed as ${ }^{\mathrm{a}}$ median and ${ }^{\mathrm{b}}$ mean. For statistical analysis, $* * *=\mathrm{p}<0.001$, ns $=\mathrm{p}>0.05$.

Table III: Correlation of heart rate variability parameters with serum TSH level in different groups ( $\mathrm{n}=80)$.

\begin{tabular}{|c|c|c|c|c|c|c|}
\hline \multirow[t]{3}{*}{ Parameters } & \multicolumn{6}{|c|}{ Groups } \\
\hline & \multicolumn{2}{|c|}{ A } & \multicolumn{2}{|c|}{$\mathrm{B}_{1}$} & \multicolumn{2}{|c|}{$\mathrm{B}_{2}$} \\
\hline & $r$ & $\mathrm{p}$ & $\mathrm{r}$ & $\mathrm{p}$ & $r$ & $\mathrm{p}$ \\
\hline Mean R-R interval & $+0.000^{\mathrm{ns}}$ & 1.000 & $-0.299^{n s}$ & 0.108 & $+0.163^{\mathrm{ns}}$ & 0.388 \\
\hline Mean Heart rate & $+0.022^{\mathrm{ns}}$ & 0.926 & $+0.249^{\mathrm{ns}}$ & 0.184 & $-0.185^{\mathrm{ns}}$ & 0.329 \\
\hline Variance & $+0.219^{n s}$ & 0.353 & $-0.028^{n s}$ & 0.882 & $+0.156^{\mathrm{ns}}$ & 0.410 \\
\hline LF n.u. & $-0.209^{n s}$ & 0.377 & $+0.363 *$ & 0.049 & $+0.081^{\mathrm{ns}}$ & 0.670 \\
\hline HF n.u. & $+0.205^{\mathrm{ns}}$ & 0.386 & $-0.381 *$ & 0.038 & $-0.059^{n s}$ & 0.757 \\
\hline $\mathrm{LF} / \mathrm{HF}$ & $-0.204^{\mathrm{ns}}$ & 0.388 & $+0.433 *$ & 0.017 & $+0.018^{n s}$ & 0.926 \\
\hline
\end{tabular}

Statistical analyses were done by Pearson's correlation coefficient (r) test.

$*=\mathrm{p}<0.05$, ns $=$ not significant, $\mathrm{n}=$ number of subjects.

J Bangladesh Soc Physiol. 2010 June; 5(1): 20-26 
Table IV: Correlation of heart rate variability parameters with serum $\mathrm{FT}_{4}$ level in different groups $(\mathrm{n}=80)$.

\begin{tabular}{|c|c|c|c|c|c|c|}
\hline \multirow[t]{3}{*}{ Parameters } & \multicolumn{6}{|c|}{ Groups } \\
\hline & \multicolumn{2}{|c|}{ A } & \multicolumn{2}{|c|}{$\mathrm{B}_{1}$} & \multicolumn{2}{|c|}{$\mathrm{B}_{2}$} \\
\hline & $\mathrm{r}$ & $\mathrm{p}$ & $\mathrm{r}$ & $\mathrm{p}$ & $\mathrm{r}$ & $\mathrm{p}$ \\
\hline Mean R-R interval & $-0.124^{\mathrm{ns}}$ & 0.604 & $-0.052^{\mathrm{ns}}$ & 0.785 & $-0.126^{\mathrm{ns}}$ & 0.509 \\
\hline Mean Heart rate & $+0.152^{\mathrm{ns}}$ & 0.524 & $+0.039^{\mathrm{ns}}$ & 0.836 & $+0.157^{\mathrm{ns}}$ & 0.406 \\
\hline Variance & $+0.048^{\mathrm{ns}}$ & 0.841 & $-0.079^{n s}$ & 0.677 & $-0.308^{n s}$ & 0.098 \\
\hline LF n.u. & $+0.187^{n s}$ & 0.430 & $+0.019^{\mathrm{ns}}$ & 0.921 & $+0.225^{\mathrm{ns}}$ & 0.232 \\
\hline HF n.u. & $-0.188^{n s}$ & 0.428 & $-0.026^{\mathrm{ns}}$ & 0.889 & $-0.283^{\mathrm{ns}}$ & 0.130 \\
\hline $\mathrm{LF} / \mathrm{HF}$ & $+0.150^{\mathrm{ns}}$ & 0.528 & $+0.137^{\mathrm{ns}}$ & 0.470 & $+0.226^{\mathrm{ns}}$ & 0.230 \\
\hline
\end{tabular}

Statistical analyses were done by Pearson's correlation coefficient (r) test.

$\mathrm{ns}=$ not significant, $\mathrm{n}=$ number of subjects.

\section{Discussion}

The present cross sectional study was undertaken to observe the relationship between both time domain and frequency domain measures of HRV like mean R-R interval, mean heart rate, variance, LF n.u. power, HF n.u. power and LF/HF ratio and excess thyroid hormone and lower level of TSH and very high $\mathrm{FT}_{4}$ levels in patients with hyperthyroidism. More over, all these correlations were also observed in healthy age and sex matched adults.

It has been suggested that along with the CNS manifestations, excess thyroid hormones usually affect every single cell of human body and results in exaggerated manifestations of hyperadrenergic state and all of them have impact on heart rate. Thyroid hormones cause increased sinoatrial nodal activity. ${ }^{17}$ In addition, these hormones potentate the metabolic activity, oxygen consumption in peripheral tissue and $b$ receptors activities. $^{20}$

In this study, sympathetic hyperactivity might be the cause of HRV dysfunction in the hyperthyroid patients of the present series which is further supported by the positive relationships of LF n.u. power with serum $\mathrm{FT}_{4}$ level. Again contribution of decreased modulation of parasympathetic activity is likely to occur in both the groups of hyperthyroid patients of the present study . The negative correlations of some parameters with serum $\mathrm{FT}_{4}$ level are also in favor of this statement. At the same time, the sympathovagal balance is shifted towards sympathetic dominance in hyperthyroid patients of the present series, which is supported by the positive correlation of LF/HF ratio with serum $\mathrm{FT}_{4}$ level. All these findings are less pronounced in treated hyperthyroids than that of untreated hyperthyroids. So, it may be plainspoken that treatment improves the conditions.

However, the exact mechanisms involved for the impairment of cardiac autonomic nervous activity in hyperthyroids of the present series can not be elucidated from this type of study. Assessment of serum or urinary catecholamines levels may be helpful to establish the involvement of neuroeffector mechanisms both centrally and peripherally in the hyperthyroid patients of the present series.

\section{Conclusion}

Heart rate variabilties are closely related with the hormones related to thyroid function in hyperthyroid state of patients and following treatment may return the patients' condition towards almost normal.

J Bangladesh Soc Physiol. 2010 June; 5(1): 20-26 


\section{Author affiliations}

*1. Md. Rasel Kabir, Assistant professor, Department of Physiology, Z. H. Sikder Women's Medical College, Dhaka. Email:raselkabir-623@gmail.com

2. Noorzahan Begum, Professor Department of Physiology, Bangabandhu Sheikh Mujib Medical University (BSMMU), Bangladesh. Email: noorzahanbeg@yahoo.com

3. Sultana Ferdousi, Assistant Professor, Department of Physiology, Bangabandhu Sheikh Mujib Medical University (BSMMU), Bangladesh. Email: sferdousiratna@gmail.com

4. Shelina Begum, Professor, Chairman, Department of Physiology, Bangabandhu Sheikh Mujib Medical University (BSMMU), Bangladesh.

5. Taskina Ali, Assistant Professor, Department of Physiology, Bangabandhu Sheikh Mujib Medical University (BSMMU), Bangladesh. Email: taskinadr@gmail.com.

\section{References}

1. Foley CM, Mc Allister RM, Hasser EM. Thyroid status influences baroreflex function and autonomic contributions to arterial pressure and heart rate. Am J Physiol Heart Circ Physiol. 2001; 280: H2061-H2068.

2. Bhat AN, Kalsotra L, Yograj S. Autonomic Reactivity with Altered Thyroid Status. JK Science. 2007; 9(2): 70-74.

3. Coulombe P, Dussault JH, Letarte J, Simmard SJ. Catecholamine Metabolism In Thyroid Diseases.I. Epinephrine Secretion Rate In Hyperthyroidism And Hypothyroidism. J Clin Endocrinol Metab. 1976; 42: 125-31.

4. Coulombe P, Dussault JH, Walker P. Catecholamine Metabolism In Thyroid Diseases.II. Norepinephrine Secretion Rate In Hyperthyroidism And Hypothyroidism. J Clin Endocrinol Metab. 1977; 44: 1185-89.

5. Fagius J, Westermark K, Karlsson A. BaroreflexGoverned Sympathetic Outflow To Muscle Vasculature Is Increased In Hypothyroidism. Clin Endocrinol. 1990; 33(2): 177-85.

6. Levey GS, Klein I. Catecholamine-Thyroid Hormone Interactions And The Cardiovascular Manifestations Of Hyperthyroidism. Am J Med. 1990; 88(6): 642-46

7. Matsukawa T, Mano T, Gotoh E, Minamisawa K, Ishii M. Altered Muscle Sympathetic Nerve Activity In Hyperthyroidism And Hypothyroidism. J Auton Nerv Syst. 1993; 42(2): 171-75.
8. Chen JL, Chiu HW, Tseng YJ, Chu WC. Hyperthyroidism Is Characterized By Both Increased Sympathetic And Decreased Vagal Modulation Of Heart Rate: Evidence From Spectral Analysis Of Heart Rate Variability. Clin Endocrinol. 2006; 64(6): 611-16.

9. Bilezikian JP, Loeb JN. The Influence Of Hyperthyroidism And Hypothyroidism On Alpha And Beta Adrenergic Receptor Systems And Adrenergic Responsiveness. Endocr Rev. 1983; 4: 378-88.

10. Levine MA, Feldman AM, Robishaw JD, Ladenson PW, Ahn TG, Moroney JF, Smallwood PM. Influence of thyroid hormone status on expression of genes encoding $G$ protein subunits in the rat heart. J Biol Chem. 1990; 265(6): 3553-60.

11. Metz LD, Seidler FJ, McCook EC, Slotkin TA. Cardiac Á-Adrenergic Receptor Expression Is Regulated By Thyroid Hormone During A Critical Developmental Period. J Mol Cell Cardiol. 1996; 28(5): 1033-44.

12. Maciel BC, Gallo LJr, Marin NJA, Maciel LM, Alves ML, Paccola GM, Iazigi N. The Role Of Autonomic Nervous System In The Resting Tachycardia Of Human Hyperthyroidism. Clin Sci. 1987; 72: 239-44.

13. Inukai $\mathrm{T}$, Kobayashi $\mathrm{I}$, Kobayashi $\mathrm{T}$, Ishii $\mathrm{A}$, Yamaguchi T, Yamaguchi Y, Washita A, Shimomura Y, Kobayashi S. Parasympathetic Nervous System In Patients With Graves' Disease Determined By R-R Interval Variations On Electrocardiogram. Exp Clin Endocrinol. 1990; 96(3): 289-95.

14. Cacciatori V, Bellavere F, Pezzarossa A, Dellera A, Gemma ML, Thomaseth K, Castello R, Moghetti T, Muggeo M. Power spectral Analysis of Heart Rate in Hyperthyroidism. J Clin Endocrinol Metab. 1996; 81: 2828-35.

15. Inukai T, Takanashi K, Kobayashi H, Fujiwara Y, Tayama K, Aso Y, Takemura Y. Power spectral analysis of variations in heart rate in patients with hyperthyroidism or hypothyroidism. Horm Metab Res. 1998; 30: 531-35.

16. Burggraaf J, Tulen JHM, Lalezari S, Schoemaker RC, De Meyer PHEM, Meinders AE, Cohen AF, Pijl H. Sympatho-Vagal Imbalance In Hyperthyroidism. Am J Physiol Endocrinol Metab. 2001; 281:E190-E195.

17. Woeber KA. Thyrotoxicosis and the Heart. N Engl J Med. 1992; 327(2): 94-98. 


\section{Article}

18. Ojamaa K, Balkman C, Klein I. Acute Effects Of Triiodothyronine On Arterial Smooth Muscle Cells. Ann Thorac Surg. 1993; 56(1): S66-67.

19. Faber J, Weinberg N, Schifter S, Mehlsen J. Haemodynamic Changes Following Treatment of Sub-clinical and Overt Hyperthyroidism. Euro J Endocrinol. 2001; 145: 391-95.

20. Klein I, Ojamaa K. Thyroid Hormone and the Cardiovascular System. N Engl J Med. 2001; 344(7): 501-9.

21. Valcavi R, Menozzi C, Roti E, Zini M, Lolli G, Roti S, Guiducci U, Portioli I. Sinus Node Function in Hyperthyroid Patients. Clin Endocrinol Metab. 1992; 75: 239-42.

22. Osman F, Gammage MD, Sheppard MC, Franklyn JA. Cardiac Dysrhythmias And Thyroid Dysfunction: The Hidden Menace? J Clin Endocrinol Metab. 2002; 87(3): 963-67.

23. Stys A, Stys T. Current clinical applications of heart rate variability. Clin Cardiol. 1998; 21(10): 71924.

24. Osman F, Franklyn JA, Daykin J, Chowdhary S, Holder RL, Sheppard MC, Gammage MD. Heart Rate Variability and Turbulence in Hyperthyroidism Before, During, and After Treatment. Am J Cardiol. 2004; 94: 465-69.

25. Malliani A, Pagani M, Lombardi M, Cerutti S. Cardiovascular Neural Regulation Explored In The Frequency Domain. Circulation. 1991; 84(2): 48292.
Relationship of Thyroid Hormones with HRV

26. Girard A, Hugues FC, Le-Jeunne C, Elghozi JL. Short Term Variability Of Blood Pressure And Heart Rate In Hyperthyroidism. Clin Auton Res. 1998; 8(3): 181-86.

27. Ewing DJ, Neilson JMM, Travis P. New Method For Assessing Cardiac Parasympathetic Activity Using 24 Hour Electrocardiograms. Br Heart J. 1984; 52: 396-402.

28. Kollai B, Kollai M. Reduced Cardio Vagal Excitability In Hyperthyroidism. Brain Res Bull. 1988; 20(6): 785-90.

29. Petretta M, Bonaduce D, Spinelli L, Vicario MLE, Nuzzo V, Marciano F, Camuso P, Sanctis VD, Lupoli G. Cardiovascular Hemodynamic and Cardiac Autonomic Control in Patients with Sub clinical and Overt Hyperthyroidism. Euro J Endocrinol. 2001; 145: 691-96.

30. Perciaccante A, Fiorentini A, Paris A, Serra P, Tubani L. Circadian Rhythm Of Autonomic Nervous System In Insulin Resistance Subjects With Normoglycemia, Impaired Fasting Glycemia, Impaired Glucose Tolerance, Type-2 Diabetes Mellitus. BMC Cardiovasc Disord. 2006; 6.

31. Barczynski M, Tabor S, Thor P. Evaluation Of Autonomic Nervous System Function With Heart Rate Variability Analysis In Patients With Hyperthyroidism And During Euthyroidism After Pharmacologic And Surgical Treatment. Folia Med Cracov. 1997; 38(3-4): 27-35. 